Jurnal Pujangga Volume 6, Nomor 2, Desember 2020

ISSN P 2443-1478

ISSN E 2443-148

\title{
ANALYSIS OF MANUK DADALI FOLKSONG IN TERMS OF VALUES
}

\author{
Fiza Asri Fauziah Habibah \\ Universitas Bina Sarana Informatika, Jakarta \\ 08979555658 \\ fiza.ffz@bsi.ac.id \\ Fadilah \\ Universitas Bina Sarana Informatika, Jakarta \\ 08984598929 \\ Fadilah.flh@bsi.ac.id
}

Received Sept 14, 2020, Revised Sept 30, 2020 , Approved Oct 15, 2020

\begin{abstract}
ABSTRAK
Penelitian ini bertujuan untuk mengetahui nilai-nilai dasar di dalam lagu rakyat Manuk Dadali dan menganalisis hubungan antara nilai-nilai dasar tersebut. Dalam menganalisis data, peneliti menggunakan teori Schwartz tentang sepuluh nilai dasar motivasi. Dalam melakukan penelitian ini, peneliti menggunakan metode kualitatif deskriptif. Metode kualitatif merupakan prosedur penelitian yang menghasilkan data deskriptif berupa kata-kata tertulis dari masyarakat maupun buku. Hasil analisis data menunjukkan bahwa terdapat tujuh nilai dasar dalam lirik lagu rakyat Manuk Dadali yaitu kekuasaan, prestasi, tradisi, kepatuhan, universalisme, kebajikan, dan keamanan. Dari masingmasing nilai, terdapat hubungan yang saling berkaitan satu dengan lainnya. Kekuasaan dengan prestasi, tradisi dengan kepatuhan, universalisme dengan kebajikan, dan keamanan dengan kepatuhan.
\end{abstract}

Kata Kunci: nilai dasar, lagu rakyat manuk dadali

\begin{abstract}
The study aimed to investigate the basic values in Manuk Dadali folksong. This study was planned also to analyze the interrelation of each values in Manuk Dadali folksong. In analyzing the data, the researchers used the theory of Schwartz about ten motivational basic values. In conducting this research, the researchers used descriptive qualitative method. The qualitative method was a research procedure which results in descriptive data whether it is from society or books. The result of the data analysis showed that there are seven basic values in the lyrics of Manuk Dadali folksong. They are power, achievement, tradition, conformity, universalism, benevolence, and security. Every values is interrelated each other. Power and achievement, tradition and conformity, universalism and benevolence, and security and conformity.
\end{abstract}

Keywords: basic values, manuk dadali folksong

\section{INTRODUCTION}

\section{Background of Research}


Jurnal Pujangga Volume 6, Nomor 2, Desember 2020

ISSN P 2443-1478

ISSN E 2443-148

A very beautiful quote by Albert Einstein reminded us how values has a great role in our life. Instead of being a successful person, there is more valuable thing than that. It is becoming a valuable person.

"Try not to become a man of success, but rather try to become a man of value"

-Albert Einstein-

When it comes to values, it seems that we care to all the things in the world. There is no word of selfish in our dictionary of life. Being success is almost a selfish goal, because we are striving to be a success for ourselves. If we are striving to be a value, we are striving to help others. Values have played an important role in any disciplines. They are used to characterize cultural groups, societies, and individuals, to trace change over time, and to explain the motivational bases of attitudes and behavior.

An object of this study is literary work, a song. Songs have special characteristic in their lyric. Song generally conveys message and meanings. The composer needs time to think, to choose the words, to read, to rethink, revise and arrange it. Then he considers its effect to the listener. There are two kinds of song related to the era, modern and traditional song. Traditional song which is analyzed in this study comes from Sundanese, Indonesia.

This study however, analyze ten motivational basic values of Schwartz's theory in Sundanese traditional song which is so called a folksong entitled Manuk Dadali. It is one of the most popular Sundanese folksong in Indonesia. Manuk Dadali clearly symbolize the country of Indonesia which officially became Indonesia's national symbol.

Manuk Dadali has a nasionalistic value, as explained in the book entitled Negara Paripurna (Plenary State) (Latif:2013). It is a Sundanese song composed by Sambas Mangundikarta which was popular in the 1960 s by topping the new charts at RRI Bandung, Indonesia which at that time was the "king" in the broadcast world of West Java. This song tells of a (bird) which is defined as a Garuda bird which is described as a mighty bird. Manuk Dadali song contains poems that breathe nationalism, apart from that, this song is very pleasant to hear, especially if it is sung using angklung, the famous West Javanese musical instrument. The more it feels, this song is full of meaning ranging from love for the nation, pride of greatness and strength, to courage to sacrifice for the country. 


\section{Statements of The Research}

1. What basic values are comprised in Manuk Dadali folksong?

2. How does interrelation among the basic values in Manuk Dadali folksong?

\section{Objectives of The Research}

1. To know the basic values existed in Manuk Dadali folksong.

2. To know the interrelation among the basic values in Manuk Dadali folksong.

\section{Literature Review}

\section{The Nature of Values}

When we think of our values, we think of what is important to us in life. Each of us holds numerous values (e.g., achievement, security, benevolence) with varying degrees of importance. A particular value may be very important to one person but unimportant to another. The value theory (Schwartz, 1992, 2006a) adopts a conception of values that specifies six main features that are implicit in the writings of many theorists:

(1) Values are beliefs linked inextricably to affect.

When values are activated, they become infused with feeling. People for whom independence is an important value become aroused if their independence is threatened, despair when they are helpless to protect it, and are happy when they can enjoy it.

(2) Values refer to desirable goals that motivate action.

People for whom social order, justice, and helpfulness are important values are motivated to pursue these goals.

(3) Values transcend specific actions and situations.

Obedience and honesty values, for example, may be relevant in the workplace or school, in business or politics, with friends or strangers. This feature distinguishes values from norms and attitudes that usually refer to specific actions, objects, or situations.

(4) Values serve as standards or criteria.

Values guide the selection or evaluation of actions, policies, people, and events. People decide what is good or bad, justified or illegitimate, worth doing or avoiding, based on possible consequences for their cherished values. But the impact of values in everyday decisions is 
ISSN P 2443-1478

ISSN E 2443-148

rarely conscious. Values enter awareness when the actions or judgments one is considering have conflicting implications for different values one cherishes.

(5) Values are ordered by importance relative to one another.

People's values form an ordered system of priorities that characterize them as individuals. Do they attribute more importance to achievement or justice, to novelty or tradition? This hierarchical feature also distinguishes values from norms and attitudes.

(6) The relative importance of multiple values guides action.

Any attitude or behavior typically has implications for more than one value. For example, attending church might express and promote tradition and conformity values at the expense of hedonism and stimulation values. The tradeoff among relevant, competing values guides attitudes and behaviors (Schwartz, 1992, 1996). Values influence action when they are relevant in the context (hence likely to be activated) and important to the actor.

The above are features of all values. What distinguishes one from another is the type of goal or motivation that it expresses.

\section{Schwartz's Value Theory}

The values theory defines ten broad values according to the motivation that underlies each of them.

\section{Self-Direction}

Self-Direction is independent thought and action--choosing, creating, exploring. Selfdirection derives from organismic needs for control and mastery and interactional requirements of autonomy and independence.

\section{Stimulation}

Stimulation is excitement, novelty, and challenge in life. Stimulation values derive from the organismic need for variety and stimulation in order to maintain an optimal, positive, rather than threatening, level of activation. This need probably relates to the needs underlying self-direction values.

\section{Hedonism}

Hedonism is pleasure or sensuous gratification for oneself. Hedonism values derive from organismic needs and the pleasure associated with satisfying them. 
ISSN P 2443-1478

ISSN E 2443-148

\section{Achievement}

Achievement is personal success through demonstrating competence according to social standards. Competent performance that generates resources is necessary for individuals to survive and for groups and institutions to reach their objectives. As defined here, achievement values emphasize demonstrating competence in terms of prevailing cultural standards, thereby obtaining social approval.

\section{Power}

Power is social status and prestige, control or dominance over people and resources. The functioning of social institutions apparently requires some degree of status differentiation. A dominance or submission dimension emerges in most empirical analyses of interpersonal relations both within and across cultures.

\section{Security}

Security is safety, harmony, and stability of society, of relationships, and of self. Security values derive from basic individual and group requirements. Some security values serve primarily individual interests (e.g., clean), others wider group interests (e.g., national security). Even the latter, however, express, to a significant degree, the goal of security for self or those with whom one identifies.

\section{Conformity}

Conformity is restraint of actions, inclinations, and impulses likely to upset or harm others and violate social expectations or norms. Conformity values derive from the requirement that individuals inhibit inclinations that might disrupt and undermine smooth interaction and group functioning. As I define them, conformity values emphasize self-restraint in everyday interaction, usually with close others.

\section{Tradition}

Tradition is respect, commitment, and acceptance of the customs and ideas that one's culture or religion provides. Groups everywhere develop practices, symbols, ideas, and beliefs that represent their shared experience and fate. These become sanctioned as valued group customs and traditions. 
ISSN P 2443-1478

ISSN E 2443-148

They symbolize the group's solidarity, express its unique worth, and contribute to its survival. They often take the form of religious rites, beliefs, and norms of behavior. Respect for tradition, humble, devout, accepting my portion in life, moderate, and spiritual life. Tradition and conformity values are especially close motivationally; they share the goal of subordinating the self to socially imposed expectations. They differ primarily in the objects to which one subordinates the self. Conformity entails subordination to persons with whom one frequently interacts-parents, teachers, and bosses. Tradition entails subordination to more abstract objects-religious and cultural customs and ideas. Conformity values exhort responsiveness to current, possibly changing expectations. Tradition values demand responsiveness to immutable expectations from the past.

\section{Benevolence}

Benevolence is preserving and enhancing the welfare of those with whom one is in frequent personal contact (the in-groups). Benevolence values derive from the basic requirement for smooth group functioning and from the organismic need for affiliation. Most critical are relations within the family and other primary groups. Benevolence values emphasize voluntary concern for others' welfare. Helpful, honest, forgiving, responsible, loyal, true friendship, mature love, sense of belonging, meaning in life, a spiritual life. Benevolence and conformity values both promote cooperative and supportive social relations. However, benevolence values provide an internalized motivational base for such behavior. In contrast, conformity values promote cooperation in order to avoid negative outcomes for self. Both values may motivate the same helpful act, separately or together.

\section{Universalism}

Universalism is understanding, appreciation, tolerance, and protection for the welfare of all people and for nature. This contrasts with the in-group focus of benevolence values. Universalism values derive from survival needs of individuals and groups. But people do not recognize these needs until they encounter others beyond the extended primary group and until they become aware of the scarcity of natural resources. People may then realize that failure to accept others who are different and treat them justly will lead to life-threatening strife. They may also realize that failure to protect the natural environment will lead to the destruction of the resources on which life depends. Universalism combines two subtypes of concern-for the welfare of those in the larger society and world and for nature. Broadminded, social justice, equality, world at peace, world of beauty, unity with nature, wisdom, protecting the environment, inner harmony and a spiritual life. 
ISSN P 2443-1478

ISSN E 2443-148

An early version of the value theory (Schwartz, 1992) raised the possibility that spirituality might constitute another near-universal value. The defining goal of spiritual values is meaning, coherence, and inner harmony through transcending everyday reality. If finding ultimate meaning is a basic human need, then spirituality might be a distinct value found in all societies. The value survey therefore included possible markers for spirituality, gleaned from widely varied sources (a spiritual life, meaning in life, inner harmony, detachment, unity with nature, accepting my portion in life, devout). However, spirituality did not demonstrate a consistent meaning across cultures. In the absence of a consistent cross-cultural meaning, spirituality was dropped from the theory despite its potential importance in many societies.

Although the theory discriminates ten values, it postulates that, at a more basic level, values form a continuum of related motivations. This continuum gives rise to the circular structure. To clarify the nature of the continuum, I note the shared motivational emphases of adjacent values:

a) power and achievement--social superiority and esteem;

b) achievement and hedonism--self-centered satisfaction;

c) hedonism and stimulation--a desire for affectively pleasant arousal;

d) stimulation and self-direction--intrinsic interest in novelty and mastery;

e) self-direction and universalism--reliance upon one's own judgment and comfort with the diversity of existence;

f) universalism and benevolence--enhancement of others and transcendence of selfish interests;

g) benevolence and tradition--devotion to one's in-group;

h) benevolence and conformity--normative behavior that promotes close relationships;

i) conformity and tradition--subordination of self in favor of socially imposed expectations;

j) tradition and security--preserving existing social arrangements that give certainty to life;

k) conformity and security--protection of order and harmony in relations;

1) security and power--avoiding or overcoming threats by controlling relationships and resources. 
Jurnal Pujangga Volume 6, Nomor 2, Desember 2020

ISSN P 2443-1478

ISSN E 2443-148

\section{RESEARCH METHOD}

This study was conducted by applying descriptive qualitative research method. Descriptive qualitative method is used when the researcher wants to describe the condition and situation of something specifically (William, 2007). The research was about basic values in Manuk Dadali folksong and interrelation among the values. The data was taken from the transcript of the song's lyrics. In analyzing the data, the researchers used the theory of Schwartz about the motivational basic values.

\section{RESULT AND DISCUSSION}

\section{Basic Values In Manuk Dadali Folksong}

\section{Category 1. Power and Achievement}

1) Mesat ngapung luhur jauh di awang-awang

This lyric means Manuk Dadali can fly high, far away in the space. The keyword of this lyric that show a power is awang-awang. The meaning of awang-awang in KBBI (Kamus Besar Bahasa Indonesia) is ruang di atas bumi; angkasa. This is metaphorically means the greatness of Manuk Dadali.

2) Meberkeun jangjangna bangun taya karingrang

This lyric means it widen its wings and stand up without a doubt. The phrase taya self confident. karingrang can be understood as without a doubt. It is a hint if Manuk Dadali typically has a high confident.

3) Sukuna ranggaos reujeung pamatukna ngeluk

This lyric means Manuk Dadali has long talons and bowed beak. Long talons and bowed beak implies that the bird is quite big. Overall, the appearance of Manuk Dadali shows the gallant bird.

4) Ngapak mega bari hiberna tarik nyuruwuk

This lyric means it seize the cloud and has the ability to fly fast. The word ngapak is taken from Indonesian Language ngepak-mengepakkan. The phrase of ngapak mega in English is flapping its wings into sky. This lyric indicated the dominance of Manuk dadali over the other birds in this world.

5) Saha anu bisa nyusul kana tandangna 
Jurnal Pujangga Volume 6, Nomor 2, Desember 2020

ISSN P 2443-1478

ISSN E 2443-148

This lyric seems a question which literally means who can match its bravery. It is called as rhetorical sentence. The real meaning of this lyric is actually a statement tends to an emphasizing. No birds can match Manuk Dadali's bravery. This analysis is also emphasized by the next lyric.

6) Gandang jeung pertentang taya bandingannana

The word gandang and pertentang in Indonesian mean cakap sikap, tingkah laku; and pandai bicara; lantang. It means competent, capable, good and penetrating, shrill. This lyric means manly and mighty nothing can compete it.

7) Taya karempan kasieun

The word Taya is actually comes from two base words, teu aya which mean no more. This lyric can be meant without hesitation and fear. It seems Manuk dadali has great guts, ready to face the world.

8) Manuk Dadali manuk panggagahna

The word Panggagahna is superlative form of the base word gagah. We use a superlative adjective to describe the extreme quality of one thing in a group of things. This lyric means Manuk dadali is the most galant bird among all the birds in the world.

9) Perlambang sakti Indonesia Jaya

This lyric explains that Manuk dadali is a great symbol of Indonesian magnificent. It is the undeniable fact. Manuk Dadali which is called Garuda in Indonesian Language is a legendary creature used as National emblem of Indonesia.

10) Manuk Dadali pangkakoncarana

Again, as the previous lyric, this lyric used a superlative adjective as well. The word pangkakoncarana means the most famous. It expresses the highest degree of Manuk

Dadali. Then, this lyric is translated as Manuk Dadali, the most famous.

11) Manuk dadali ngandung siloka sinatria

The phrases siloka sinatria means a symbol of chivalry. So this lyric tells us that Manuk Dadali is a chivalry.

\section{Category 2. Tradition and Conformity}

1) Dipikagimir dipikaserab ku sasama

Dipikagimir dipikaserab ku sasama means respected and loved by others.

\section{Category 3. Universalism and Benevolence}


Jurnal Pujangga Volume 6, Nomor 2, Desember 2020

ISSN P 2443-1478

ISSN E 2443-148

1) Resep ngahiji rukun sakabehna

This lyric means Happy to be united, get along well. This lyric demonstrates understanding, appreciation, tolerance, and protection for the welfare of all birds and for nature as well.

2) Silih pikanyaah teu inggis bela pati

Silih pikanyaah teu inggis bela pati means love each other and do not hesitate to sacrifice lives. Helpful, honest, forgiving, responsible, loyal, true friendship, mature love, sense of belonging, they are all the meaning existed in this lyric.

\section{Category 4. Security and Conformity}

\section{1) Hirup sauyunan tara pahiri-hiri}

Hirup sauyunan tara pahiri-hiri means living together without envy. This means Manuk Dadali can socialize well in the environment. It demonstrates protection to others and harmony in relation.

\section{CONCLUSION}

The values are one important, especially central component of our self and personality, distinct from attitudes, beliefs, norms, and traits. Based on Schwartz's theory of ten motivational values, there are seven basic values in Manuk Dadali folksong. They are power, achievement, tradition, conformity, universalism, benevolence, and security. Every values is interrelated each other. Power and achievement demonstrate social superiority and esteem; tradition and conformity demonstrate subordination of self in favor of socially imposed expectations; universalism and benevolence demonstrate enhancement of others and transcendence of selfish interest; security and conformity demonstrate protection of order and harmony in relation. 


\section{REFERENCES}

Dasopang, Aisyah Fitriani. 2017. "Semantic and Semiotic Analysis of "Rere Mana Rere" Song in the Culture of Mandailing". Dalam International Journal of Linguistics Macrothink Institute. Volume 9, Nomor 3, Halaman 15-24. Medan.

Dincel, Betul keray. 2017. “Analysis of Children's songs in Terms of Values”. Dalam Journal of Education and Practice. Volume 8, Nomor 26, Halaman 64-71. Turki.

https://imujio.com/kebudayaan-jawa-barat/ (Diakses 6 Mei 2020)

https://kamuslengkap.com/kamus/sunda-indonesia/arti-kata/ (Diakses 1 Juni 2020)

https://today.line.me/id/article/Lirik+Lagu+Manuk+Dadali+Terjemahan+Lengkap-0E7kj2

(Diakses 1 Mei 2020)

Latif, Y. 2013. Negara Paripurna (Plenary State). Jakarta: Gramedia Pustaka Utama.

Mahmudah, S.R., and Sumaryadi. 2018. "Cultivating the Spirit of Nasionalism through the song Manuk Dadali". Dalam Proceedings of the $1^{\text {st }}$ International Conference of the Music Education Community. October 25-26. Yogyakarta.

Schwartz, S.H. 2012. "An Overview of the Schwartz Theory of Basic Values". Dalam Online Readings in Psychology and Culture. Unit 2, Subunit 1. The Hebrew University of Jerusalem. 